Supporting Information for:

\title{
Perpendicular Organization of Macromolecules: Synthesis and Alignment Studies of a Soluble Poly(iptycene)
}

Samuel W. Thomas III ${ }^{1}$, Timothy M. Long ${ }^{1}$, Brian D. Pate ${ }^{2,3}$, Steven R. Kline ${ }^{4}$, Edwin L. Thomas $^{2,3}$ and Timothy M. Swager*1,3

Department of Chemistry ${ }^{l}$, Department of Materials Science and Engineering ${ }^{2}$ and Institute for Soldier Nanotechnologies, ${ }^{3}$ Massachusetts Institute of Technology, 77 Massachusetts Avenue, Cambridge, Massachusetts 02139; NIST Center for Neutron Research ${ }^{4}$, Gaithersburg, Maryland 20899.

\section{Experimental Section}

General. ${ }^{1} \mathrm{H}$ NMR spectra for all compounds were recorded on a Varian MERCURY (300Mhz) instrument, using deuterochloroform as a reference or internal deuterium lock. The chemical shift data for each signal are given in units of $\delta(\mathrm{ppm})$ relative to tetramethylsilane (TMS) where $\delta(\mathrm{TMS})=0$, and referenced to the solvent residual. ${ }^{13} \mathrm{C}$ NMR spectra were recorded on a Varian MERCURY (75MHz) instrument using internal deuterium lock and proton decoupling. High resolution mass spectra (HRMS) were obtained on a Finnigan MAT 8200 system using sector double focus and an electron impact source with an ionizing voltage of $70 \mathrm{~V}$, and with a Bruker DALTONICS APEX II, 3 Tesla, FT-ICR-MS with ESI source or EI/CI source. Ultraviolet-visible absorption spectra were measured with a Cary $50 \mathrm{UV} /$ Visible spectrometer. Polarized fluorescence spectra were measured with a SPEX Fluorolog- $\tau 3$ fluorimeter (model FL312, 450W xenon lamp) equipped with a 1935B polarization kit. Polymer molecular weights were determined by Gel Permeation Chromatography (GPC) running with tetrahydrofuran as the eluent versus polystyrene standards (PolySciences). A Hewlett Packard series 1100 HPLC instrument equipped with a Plgel $5 \mathrm{~mm}$ Mixed-C (300 x $7.5 \mathrm{~mm})$ column was used. Preparative-scale GPC was performed using THF as the eluent with a Rainin HPLC instrument equipped with an isocratic solvent pump and UV/Vis detector and a preparative-scale Plgel column.

All synthetic manipulations were performed under an argon atmosphere using standard Schlenk techniques unless otherwise indicated. Solvents were purified and dried by standard techniques. ${ }^{1}$ N-bromosuccinimide (NBS) was purified by recrystallization from hot water. All other chemicals were of reagent grade and used without further purification. 1,4-dimethoxyanthracene ${ }^{2}$ and 7,16-(2',3'-anthraceno)-7,16dihydroheptacene ${ }^{3}$ were prepared according to literature procedures.

\section{Scheme S-1}

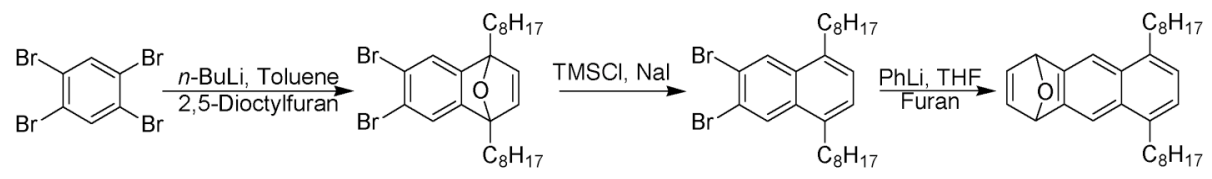


1,4-epoxy-1,4-dihydro-6,7-dibromo-1,4-dioctylnaphthalene. To a $0^{\circ} \mathrm{C}$ solution of 2,5dioctylfuran $(65 \mathrm{~mL})$ and $1,2,4,5$-tetrabromobenzene $(39.4 \mathrm{~g}, 100 \mathrm{mmol})$ in $1.5 \mathrm{~L}$ toluene, under Ar, was added $n$-BuLi $(49 \mathrm{~mL}, 2.5 \mathrm{M}$ in hexanes, $122.5 \mathrm{mmol})$ dropwise over the course of 3.5 hours. The solution was stirred at $0^{\circ} \mathrm{C}$ for 2 hours, allowed to warm to room temperature, and stirred overnight. It was quenched by the careful addition of 10 $\mathrm{mL} \mathrm{MeOH}$ and washed with water and saturated $\mathrm{NaCl}$. Drying over $\mathrm{MgSO}_{4}$, filtration and removal of solvent in vacuo gave an orange oil. Purification by column chromatography (silica gel, hexanes followed by $5: 1$ hexanes: $\mathrm{CHCl}_{3}$ ) yielded the product as a pale yellow oil $\left(34.87 \mathrm{~g}, 66 \%\right.$ yield). ${ }^{1} \mathrm{H}$ NMR $\left(300 \mathrm{MHz}, \mathrm{CDCl}_{3}\right) \delta 7.29(\mathrm{~s}, 2 \mathrm{H})$ $6.72(\mathrm{~s}, 2 \mathrm{H}) 2.18(\mathrm{~m}, 4 \mathrm{H}) 1.57(\mathrm{~m}, 4 \mathrm{H}) 1.50-1.20(\mathrm{~m}, 20 \mathrm{H}) 0.89(\mathrm{t}, 6 \mathrm{H}, \mathrm{J}=7.2 \mathrm{~Hz}) ;{ }^{13} \mathrm{C}$ NMR (75 MHz, $\left.\mathrm{CDCl}_{3}\right) \delta$ 154.1, 145.6, 124.3, 120.4, 91.9, 32.2, 30.3, 29.7, 29.6, 29.4, 24.9, 23.0, 14.5; HRMS (EI): calcd. For $\mathrm{C}_{26} \mathrm{H}_{38} \mathrm{Br}_{2} \mathrm{O}, 524.1289$ (M+), found 524.1278.

2,3-dibromo-5,8-dioctylnaphthalene. To a suspension of 1,4-epoxy-1,4-dihydro-6,7dibromo-1,4-dioctylnaphthalene $(10.52 \mathrm{~g}, 20 \mathrm{mmol})$ and dry $\mathrm{NaI}(9.00 \mathrm{~g}, 60 \mathrm{mmol})$ in $200 \mathrm{~mL}$ acetonitrile and, under $\mathrm{Ar}$, was added TMS-Cl ( $8.0 \mathrm{~mL}, 60 \mathrm{mmol})$ dropwise. The solution turned from yellow to red-orange during the addition and was stirred at room temperature for 3 hours. Within 10 minutes, the starting material had dissolved and a new white precipitate had formed. The reaction was quenched by pouring into a solution of $\mathrm{NaHSO}_{3}$ (aq.) and the product extracted with $\mathrm{CH}_{2} \mathrm{Cl}_{2}$. After washing the combined organic layers with water and drying over $\mathrm{MgSO}_{4}$, filtration and removal of solvent in vacuo yielded a pale orange solid which was recrystallized from $\mathrm{THF} /$ methanol to yield the product $(7.89 \mathrm{~g}, 77 \%$ yield $)$ as a white solid. ${ }^{1} \mathrm{H}$ NMR $\left(300 \mathrm{MHz}, \mathrm{CDCl}_{3}\right) \delta$ $8.28(\mathrm{~s}, 2 \mathrm{H}) 7.22(\mathrm{~s}, 2 \mathrm{H}) 2.93(\mathrm{t}, 4 \mathrm{H}, \mathrm{J}=7.5 \mathrm{~Hz}) 1.68(\mathrm{~m}, 4 \mathrm{H}) 1.45-1.20(\mathrm{~m}, 24 \mathrm{H}) 0.88(\mathrm{t}$, $6 \mathrm{H}, \mathrm{J}=6.6 \mathrm{~Hz}) ;{ }^{13} \mathrm{C} \mathrm{NMR}\left(75 \mathrm{MHz}, \mathrm{CDCl}_{3}\right) \delta 136.4,132.4,129.5,127.0,121.6,33.0$, 32.2, 30.9, 30.0, 29.7, 29.6, 23.0, 14.4; HRMS (EI): Calcd. For $\mathrm{C}_{26} \mathrm{H}_{38} \mathrm{Br}_{2}, 508.1340$ $(\mathrm{M}+)$, found: 508.1348 . M.P. $49-51^{\circ} \mathrm{C}$.

1,4-epoxy-1,4-dihydro-5,8-dioctylanthracene. To a solution of 2,3-dibromo-5,8dioctylnaphthalene $(5.10 \mathrm{~g}, 10.0 \mathrm{mmol})$ in $75 \mathrm{~mL}$ furan and $75 \mathrm{~mL}$ THF under $\mathrm{Ar}$ at $0^{\circ} \mathrm{C}$, was added $\mathrm{PhLi}\left(1.8 \mathrm{M}_{\text {in }} \mathrm{Et}_{2} \mathrm{O}\right.$ :cyclohexane $\left.70: 30,7.5 \mathrm{~mL}, 13.5 \mathrm{mmol}\right)$ dropwise over 90 minutes. The solution was maintained at $0^{\circ} \mathrm{C}$ for 2 hours, warmed slowly to room temperature and stirred at room temperature for 15 hours. Excess PhLi was quenched by careful addition of $\mathrm{MeOH}$. Water was added and the solution extracted with chloroform. The combined organic layers were washed with water and saturated aqueous $\mathrm{NaCl}$; drying over $\mathrm{MgSO}_{4}$, filtration, and removal of solvent in vacuo yielded a tan solid. Column chromatography (silica gel, hexanes: chloroform 1:2) gave the product $(3.15 \mathrm{~g}$, $74 \%)$ as a white to slightly green solid. ${ }^{1} \mathrm{H}$ NMR $\left(300 \mathrm{MHz}, \mathrm{CDCl}_{3}\right): \delta 7.82(\mathrm{~s}, 2 \mathrm{H}) 7.18$ $(\mathrm{s}, 2 \mathrm{H}) 6.98(\mathrm{~s}, 2 \mathrm{H}) 5.83(\mathrm{~s}, 2 \mathrm{H}) 2.95(\mathrm{t}, 4 \mathrm{H}, \mathrm{J}=7.8 \mathrm{~Hz}) 1.68$ (pent., 4H) 1.50-1.20 (m, 20H) $0.88(\mathrm{t}, 6 \mathrm{H}, \mathrm{J}=6.6 \mathrm{~Hz}) ;{ }^{13} \mathrm{C} \mathrm{NMR}\left(75 \mathrm{MHz}, \mathrm{CDCl}_{3}\right): \delta 143.3,141.8,137.3,130.4$, 126.3 , 115.6, 82.3 33.7, 32.3, 31.3, 30.2, 29.8, 29.7, 23.0, 14.5; HRMS (EI): Calc. For $\mathrm{C}_{30} \mathrm{H}_{42} \mathrm{O}, 418.3236(\mathrm{M}+)$, found 418.3233 . M.P. $71-73^{\circ} \mathrm{C}$. 
Scheme S-2
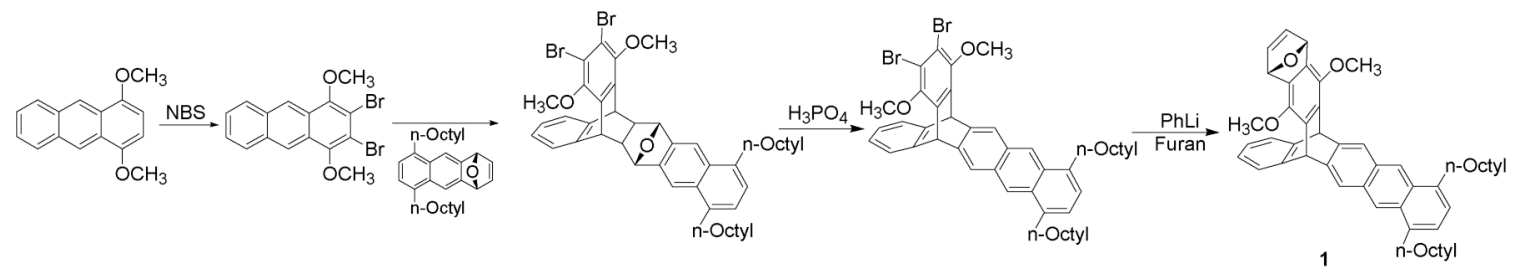

2,3-dibromo-1,4-dimethoxyanthracene. A solution of 1,4-dimethoxyanthracene (3.0 g, $12.6 \mathrm{mmol})$ and N-bromosuccinimide $(5.0 \mathrm{~g}, 28.0 \mathrm{mmol})$ in $100 \mathrm{~mL}$ DMF was stirred at room temperature in the absence of light, and under Ar for 16 hours. Then, $0.5 \mathrm{~g}$ additional NBS was added and stirring continued for 2 hours. The solution was poured into dilute $\mathrm{NH}_{4} \mathrm{Cl}$ (aq.) and extracted with chloroform. The combined chloroform extracts were washed successively with $0.1 \mathrm{~N} \mathrm{NaOH}$, water, and saturated $\mathrm{NaCl}$. Drying over $\mathrm{MgSO}_{4}$, filtration, and removal of solvent in vacuo yielded a crude orange solid which was subjected to column chromatography (silica gel, $\mathrm{CH}_{2} \mathrm{Cl}_{2}$ :hexanes $1: 1$ ) and recrystallized from hexanes to give the desired product $(2.52 \mathrm{~g}, 51 \%$ yield $)$ as bright yellow needles. ${ }^{1} \mathrm{H}$ NMR $\left(300 \mathrm{MHz}, \mathrm{CDCl}_{3}\right) \delta 8.66(\mathrm{~s}, 2 \mathrm{H}) 8.05(\mathrm{dd}, 2 \mathrm{H}, \mathrm{J}=6.0 \mathrm{~Hz}, \mathrm{~J}=$ $3.3 \mathrm{~Hz}) 7.54(\mathrm{dd}, 2 \mathrm{H}, \mathrm{J}=6.6 \mathrm{~Hz}, \mathrm{~J}=3.0 \mathrm{~Hz}) 4.08(\mathrm{~s}, 6 \mathrm{H}) ;{ }^{13} \mathrm{C} \mathrm{NMR}\left(75 \mathrm{MHz}, \mathrm{CDCl}_{3}\right)$ $\delta$ 151.2, 132.3, 128.7, 126.8, 126.4, 122.1, 114.8, 61.7; HRMS (EI): calc. For $\mathrm{C}_{16} \mathrm{H}_{12} \mathrm{O}_{2} \mathrm{Br}_{2}, 393.9204(\mathrm{M}+)$, found 393.9213. M.P. $171-172^{\circ} \mathrm{C}$.

syn/anti-[exo-5,14-(1',2'-benzeno)-2,3-dibromo-6,13-epoxy-5,5a,6,13,13a,14hexahydro-1,4-dimethoxy-8,11-dioctylpentacene]. A solution of 2,3-dibromo-1,4dimethoxyanthracene $(396 \mathrm{mg}, 1.00 \mathrm{mmol})$ and 1,4-epoxy-1,4-dihydro-5,8dioctylanthracene $(430 \mathrm{mg}, 1.03 \mathrm{mmol})$ in $20 \mathrm{~mL}$ decalin was heated to $190^{\circ} \mathrm{C}$ for 96 hours. Cooling and removal of solvent in vacuo yielded the desired product as an orangebrown solid in $96 \%$ yield. Analytically pure samples were obtained by removal of remaining anthracene by sublimation $\left(220^{\circ} \mathrm{C}, 30\right.$ mtorr $) .{ }^{1} \mathrm{H}$ NMR $\left(500 \mathrm{MHz}, \mathrm{CDCl}_{3}\right): \delta$ $7.76(\mathrm{~s}, 2 \mathrm{H}) 7.75(\mathrm{~s}, 2 \mathrm{H}) 7.36(\mathrm{dd}, 2 \mathrm{H}, \mathrm{J}=5.6 \mathrm{~Hz}, \mathrm{~J}=3.2 \mathrm{~Hz}) 7.27(\mathrm{dd}, 2 \mathrm{H}, \mathrm{J}=5.6 \mathrm{~Hz}, \mathrm{~J}$ $=3.2 \mathrm{~Hz}) 7.22(\mathrm{dd}, 2 \mathrm{H}, \mathrm{J}=7.0 \mathrm{~Hz}, \mathrm{~J}=3.0 \mathrm{~Hz}) 7.16(\mathrm{~s}, \mathrm{H}) 7.06(\mathrm{dd}, 2 \mathrm{H}, \mathrm{J}=6.5 \mathrm{~Hz}, \mathrm{~J}=$ $3.2 \mathrm{~Hz}) 5.20(\mathrm{~s}, \mathrm{H}) 5,14(\mathrm{~s}, \mathrm{H}) 4.94(\mathrm{~s}, \mathrm{H}) 4.90(\mathrm{~s}, \mathrm{H}) 3.93(\mathrm{~s}, 6 \mathrm{H}) 3.84(\mathrm{~s}, 6 \mathrm{H}) 2.94(\mathrm{~m}$, $4 \mathrm{H}) 2.43(\mathrm{~s}, 2 \mathrm{H}) 2.38(\mathrm{~s}, 2 \mathrm{H}) 1.65(\mathrm{~m}, 4 \mathrm{H}) 1.45-1.20(\mathrm{~m}, 20 \mathrm{H}) 0.88(\mathrm{t}, 6 \mathrm{H}, \mathrm{J}=6.9 \mathrm{~Hz})$; ${ }^{13} \mathrm{C}$ NMR $\left(125 \mathrm{MHz}, \mathrm{CDCl}_{3}\right)$ : $\delta 150.3,149.7,146.4,143.3,140.7,138.5,137.5,136.0$, $131.5,126.9,126.5,125.9,124.2,124.0,118.3,118.1,114.1,81.8,81.7,62.1,49.2$, 48.7, 42.3, 42.2, 33.6, 32.1, 31.1, 30.1, 30.0, 29.7, 29.5, 22.9, 14.3; HRMS (EI): Calcd. For $\mathrm{C}_{46} \mathrm{H}_{54} \mathrm{Br}_{2} \mathrm{O}_{3}, 812.2439(\mathrm{M}+)$, found: 812.2418. M.P. $71-74^{\circ} \mathrm{C}$.

\section{5,14-(1', 2'-benzeno)-2,3-dibromo-5,14-dihydro-1,4-dimethoxy-8,11-}

dioctylpentacene. To solid syn/anti-[exo-5,14-(1',2'-benzeno)-2,3-dibromo-6,13-epoxy5,5a,6,13,13a,14-hexahydro-1,4-dimethoxy-8,11-dioctylpentacene] (367 mg, $0.45 \mathrm{mmol})$, polyphosphoric acid $(45 \mathrm{~g})$ was added and the mixture was heated to $150^{\circ} \mathrm{C}$ for 90 minutes. The reaction was cooled and carefully quenched with water. Organics were extracted with chloroform, washed with saturated $\mathrm{NaHCO}_{3}$ and, saturated $\mathrm{NaCl}$, and dried over $\mathrm{MgSO}_{4}$. Filtration and removal of solvent in vacuo gave crude desired product that was used without further purification $(229 \mathrm{mg}, 64 \%) .{ }^{1} \mathrm{H} \mathrm{NMR}\left(300 \mathrm{MHz}, \mathrm{CDCl}_{3}\right)$ : 
$\delta 8.50(\mathrm{~s}, 2 \mathrm{H}) 8.03(\mathrm{~s}, 2 \mathrm{H}) 7.52(\mathrm{dd}, 2 \mathrm{H}, \mathrm{J}=5.6 \mathrm{~Hz}, \mathrm{~J}=3.2 \mathrm{~Hz}) 7.23(\mathrm{~s}, 2 \mathrm{H}) 7.13(\mathrm{dd}$, $2 \mathrm{H}, \mathrm{J}=5.6 \mathrm{~Hz}, \mathrm{~J}=3.2 \mathrm{~Hz}) 5.95(\mathrm{~s}, 2 \mathrm{H}) 4.00(\mathrm{~s}, 6 \mathrm{H}) 3.15(\mathrm{t}, 4 \mathrm{H}, \mathrm{J}=6.2 \mathrm{~Hz}) 1.82(\mathrm{~m}, 4 \mathrm{H})$ $1.50(\mathrm{~m}, 4 \mathrm{H}) 1.42-1.25(\mathrm{~m}, 16 \mathrm{H}) 0.93(\mathrm{t}, 6 \mathrm{H}, \mathrm{J}=6.6 \mathrm{~Hz}) ;{ }^{13} \mathrm{C}$ NMR $\left(75 \mathrm{MHz}, \mathrm{CDCl}_{3}\right): \delta$ $149.8,143.3,139.5,138.7,136.9,131.2,129.7,126.3,124.6,124.2$, 122.9, 122.3, 118.2 , 62.1, 48.5, 33.6, 32.2, 31.9, 30.8, 30.2, 29.8, 29.6, 23.0, 14.5; HRMS (EI): Calcd. for $\mathrm{C}_{46} \mathrm{H}_{52} \mathrm{O}_{2} \mathrm{Br}_{2}, 794.2334(\mathrm{M}+)$, found 794.2311. M.P. 90-92 ${ }^{\circ} \mathrm{C}$.

6,15-(1',2'-benzeno)-1,4-epoxy-1,4,6,15-tetrahydro-5,16-dimethoxy-9,12dioctylhexacene. (1) To a solution of 5,14-(1', 2'-benzeno)-2,3-dibromo-5,14-dihydro1,4-dimethoxy-8,11-dioctylpentacene $(1.13 \mathrm{~g}, 1.40 \mathrm{mmol})$ in $15 \mathrm{~mL}$ furan and $10 \mathrm{~mL}$ THF under $\mathrm{Ar}$ at $0^{\circ} \mathrm{C}$, was added $\mathrm{PhLi}\left(1.8 \mathrm{M}, \mathrm{Et}_{2} \mathrm{O}\right.$ :cyclohexane 70:30, $1.25 \mathrm{~mL}, 2.25$ mmol) dropwise over 2 hours. The solution was maintained at $0^{\circ} \mathrm{C}$ for 2 hours, warmed slowly to room temperature over 2 hours and then excess $\mathrm{PhLi}$ was quenched by careful addition of $2 \mathrm{~mL} \mathrm{MeOH}$. Water was added and the solution extracted with dichloromethane. The combined organic layers were washed with water and saturated aqueous $\mathrm{NaCl}$. Drying over $\mathrm{MgSO}_{4}$, filtration, and removal of solvent in vacuo yielded an orange oil. Column chromatography (silica gel, hexanes:chloroform 2:5) allowed for the separation of the two diastereomeric products (1a, $351 \mathrm{mg}$; $\mathbf{1 b}, 359 \mathrm{mg}$; total yield $710 \mathrm{mg}, 72 \%)$.

1a: ${ }^{1} \mathrm{H}$ NMR $\left(300 \mathrm{MHz}, \mathrm{CDCl}_{3}\right): \delta 8.40(\mathrm{~s}, 2 \mathrm{H}) 7.90(\mathrm{~s}, 2 \mathrm{H}) 7.43(\mathrm{dd}, 2 \mathrm{H}, \mathrm{J}=5.4 \mathrm{~Hz}, \mathrm{~J}=$ $3.3 \mathrm{~Hz}) 7.15(\mathrm{~s}, 2 \mathrm{H}) 7.03(\mathrm{dd}, 2 \mathrm{H}, \mathrm{J}=5.4 \mathrm{~Hz}, \mathrm{~J}=3.3 \mathrm{~Hz}) 6.95(\mathrm{~s}, 2 \mathrm{H}) 5.90(\mathrm{~s}, 2 \mathrm{H}) 5.83$ $(\mathrm{s}, 2 \mathrm{H}) 3.93(\mathrm{~s}, 6 \mathrm{H}) 3.09(\mathrm{t}, 4 \mathrm{H}, \mathrm{J}=7.8 \mathrm{~Hz}) 1.76(\mathrm{~m}, 4 \mathrm{H}) 1.5-1.2(\mathrm{~m}, 16 \mathrm{H}) 0.88(\mathrm{t}, 6 \mathrm{H}, \mathrm{J}$ $=6.9 \mathrm{~Hz}) ;{ }^{13} \mathrm{C} \mathrm{NMR}\left(75 \mathrm{MHz}, \mathrm{CDCl}_{3}\right): \delta 145.2,144.6,142.7,140.9,136.9,136.3,136.0$, 131.0, 129.7, 125.7, 124.4, 123.9, 122.7, 121.7, 81.0, 61.8, 47.7, 33.6, 32.2, 30.8, 30.2, 29.8, 29.6, 23.0, 14.5; HRMS (EI): Calcd. for $\mathrm{C}_{50} \mathrm{H}_{56} \mathrm{O}_{3}, 704.4230(\mathrm{M}+)$, found 704.4205. M.P. $153-155^{\circ} \mathrm{C}$ (polymerization).

1b: ${ }^{1} \mathrm{H}$ NMR $\left(300 \mathrm{MHz}, \mathrm{CDCl}_{3}\right): \delta 8.40(\mathrm{~s}, 2 \mathrm{H}) 7.90(\mathrm{~s}, 2 \mathrm{H}) 7.42(\mathrm{dd}, 2 \mathrm{H}, \mathrm{J}=5.4 \mathrm{~Hz}, \mathrm{~J}=$ $3.3 \mathrm{~Hz}) 7.14(\mathrm{~s}, 2 \mathrm{H}) 7.02(\mathrm{dd}, 2 \mathrm{H}, \mathrm{J}=5.6 \mathrm{~Hz}, \mathrm{~J}=3.2 \mathrm{~Hz}) 6.92(\mathrm{~s}, 2 \mathrm{H}) 5.91(\mathrm{~s}, 2 \mathrm{H}) 5.83$ $(\mathrm{s}, 2 \mathrm{H}) 3.92(\mathrm{~s}, 6 \mathrm{H}) 3.08(\mathrm{t}, 4 \mathrm{H}, \mathrm{J}=7.5 \mathrm{~Hz}) 1.75(\mathrm{~m}, 4 \mathrm{H}) 1.5-1.2(\mathrm{~m}, 20 \mathrm{H}) 0.88(\mathrm{t}, 6 \mathrm{H}, \mathrm{J}$ $=6.6 \mathrm{~Hz}) ;{ }^{13} \mathrm{C} \mathrm{NMR}\left(75 \mathrm{MHz}, \mathrm{CDCl}_{3}\right): \delta 145.2,144.4,142.7,141.1,136.9,136.3,136.0$, 131.0, 129.7, 125.7, 124.4, 123.9, 122.7, 121.6, 81.0, 61.9, 47.7, 33.6, 32.2, 30.9, 30.2, 29.8, 29.6, 23.0, 14.5; HRMS (EI): Calcd. For $\mathrm{C}_{50} \mathrm{H}_{56} \mathrm{O}_{3}, 704.4230(\mathrm{M}+)$, found 704.4247. M.P. $75^{\circ} \mathrm{C}$ (polymerization).

\section{Scheme S-3}

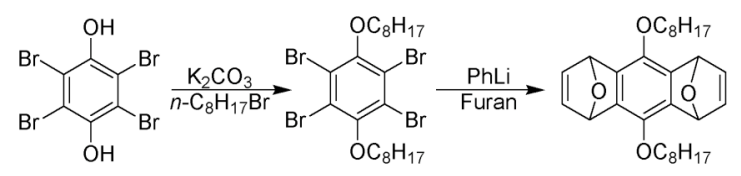

2,3,5,6-tetrabromo-1,4-dioctyloxybenzene. A solution of 1,2,4,5-

tetrabromohydroquinone $(8.50 \mathrm{~g}, 20 \mathrm{mmol})$, potassium carbonate $(6.02 \mathrm{~g}, 44 \mathrm{mmol})$ and $n$-octyl bromide $(9.33 \mathrm{~mL}, 54 \mathrm{mmol})$ in $80 \mathrm{~mL} \mathrm{DMF}$ was heated under Ar to $60^{\circ} \mathrm{C}$ for 2 days. The solution was poured into $600 \mathrm{~mL}$ ether and washed with dilute $\mathrm{NH}_{4} \mathrm{Cl}$ (aq.). Drying over $\mathrm{MgSO}_{4}$, filtration, and removal of solvent in vacuo yielded a brown oil which solidified on drying under vacuum. Recrystallization from THF/MeOH yielded the desired product as a white solid (11.76 g, 91\% yield). ${ }^{1} \mathrm{H} \mathrm{NMR}\left(500 \mathrm{MHz}, \mathrm{CDCl}_{3}\right)$ : 
ठ $3.96(\mathrm{t}, \mathrm{J}=6.8 \mathrm{~Hz}) 1.87(\mathrm{~m}, 4 \mathrm{H}) 1.51(\mathrm{~m}, 4 \mathrm{H}) 1.4-1.2(\mathrm{~m}, 16 \mathrm{H}) 0.89(\mathrm{t}, 6 \mathrm{H}, \mathrm{J}=7.5 \mathrm{~Hz})$;

${ }^{13} \mathrm{C} \mathrm{NMR}\left(125 \mathrm{MHz}, \mathrm{CDCl}_{3}\right): \delta$ 152.2, 121.6, 73.8, 32.1, 30.1, 29.6, 29.5, 26.1, 22.9,

14.3; HRMS (EI): Calcd. For $\mathrm{C}_{22} \mathrm{H}_{34} \mathrm{Br}_{4} \mathrm{O}_{2}, 645.9292$ (M+), found 645.9274. M.P. 42$43^{\circ} \mathrm{C}$.

syn/anti-1,4:5,8-diepoxy-1,4,5,8,-tetrahydro-9,10-dioctyloxyanthracene. A solution of 2,3,5,6-tetrabromo-1,4-dioctyloxybenzene $(3.25 \mathrm{~g}, 5.00 \mathrm{mmol})$ in $40 \mathrm{~mL}$ furan and 50 $\mathrm{mL}$ THF under $\mathrm{Ar}$ was cooled to $0^{\circ} \mathrm{C}$ and $\mathrm{PhLi}(1.80 \mathrm{M}$ ether:cyclohexane $70: 30,10.0$ $\mathrm{mL}, 18.0 \mathrm{mmol}$ ) was added dropwise over 90 minutes. The solution was maintained at $0^{\circ} \mathrm{C}$ for 2 hours, warmed slowly to room temperature and stirred at room temperature for 15 hours. Excess PhLi was quenched by careful addition of $\mathrm{MeOH}$. Water was added and the solution extracted with chloroform. The combined organic layers were washed with water and saturated aqueous $\mathrm{NaCl}$. Drying over $\mathrm{MgSO}_{4}$, filtration, and removal of solvent in vacuo yielded an orange oil which solidified while drying under vacuum. Column chromatography (silica gel, dichloromethane) yielded the syn-isomer. The antiisomer was eluted by changing the solvent to chloroform after the first has eluted. Total yield $1.563 \mathrm{~g}$ (syn: $0.833 \mathrm{~g}$, anti: $0.735 \mathrm{~g}, 67 \%$ overall yield)

syn: ${ }^{1} \mathrm{H}$ NMR $\left(300 \mathrm{MHz} \mathrm{CDCl}_{3}\right)$ : $\delta 7.05(\mathrm{~s}, 2 \mathrm{H}) 5.81(\mathrm{~s}, 2 \mathrm{H}) 4.00(\mathrm{dt}, 2 \mathrm{H}, \mathrm{J}=9.0 \mathrm{~Hz}, \mathrm{~J}=$ $7.0 \mathrm{~Hz}) 3.86(\mathrm{dt}, 2 \mathrm{H}, \mathrm{J}=9.0 \mathrm{~Hz}, \mathrm{~J}=7.0 \mathrm{~Hz}) 1.73(\mathrm{~m}, 4 \mathrm{H}) 1.5-1.2(\mathrm{~m}, 20 \mathrm{H}) 0.89$ (t, 6H, J $=7.0 \mathrm{~Hz}) ;{ }^{13} \mathrm{C} \mathrm{NMR}\left(75 \mathrm{MHz}, \mathrm{CDCl}_{3}\right): \delta 143.4,143.2,139.4,81.0,73.9,32.0,30.2,29.6$, 29.5, 26.2, 22.9, 14.3; HRMS (EI): Calcd. for $\mathrm{C}_{30} \mathrm{H}_{42} \mathrm{O}_{4}, 466.3083$ (M+), found 466.3094 . M.P $>98-99^{\circ} \mathrm{C}$.

anti: ${ }^{1} \mathrm{H} \mathrm{NMR}\left(300 \mathrm{MHz}, \mathrm{CDCl}_{3}\right): \delta 7.04(\mathrm{~s}, 2 \mathrm{H}) 5.82(\mathrm{~s}, 2 \mathrm{H}) 3.95(\mathrm{t}, 4 \mathrm{H}, \mathrm{J}=6.5 \mathrm{~Hz})$ $1.71(\mathrm{~m}, 4 \mathrm{H}) 1.5-1.2(\mathrm{~m}, 20 \mathrm{H}) 0.89(\mathrm{t}, 6 \mathrm{H}, \mathrm{J}=7.0 \mathrm{~Hz}) ;{ }^{13} \mathrm{C} \mathrm{NMR}\left(75 \mathrm{MHz}, \mathrm{CDCl}_{3}\right): \delta$ 143.4, 143.3, 139.5, 81.1, 73.6, 32.0, 30.2, 29.5, 29.4, 26.2, 22.9, 14.3; HRMS (EI): Calcd. for $\mathrm{C}_{30} \mathrm{H}_{42} \mathrm{O}_{4}, 466.3083(\mathrm{M}+)$, found 466.3099. M.P. $81-82^{\circ} \mathrm{C}$.

Polymerization of 1: Into a short length of heat-shrinkable Teflon tubing, which was stoppered at one end with the end of a glass rod (slightly larger than the diameter of the tubing) was added $\mathbf{1}$ (plus $\mathbf{2}$ and $\mathbf{3}$ in the appropriate ratios if making a crosslinked polymer). This tube was transferred into a dry box where THF (to a concentration of 0.5 M) was added. The remaining end of the tube was closed with another glass rod.

The high pressure reaction chamber (manufactured by Harwood Engineering, Walpole MA) employs a hand-operated hydraulic pump, a 1:1 mixture of ethylene glycol and water as the hydraulic fluid, and a differential-area piston to expose the reaction tube to hyperbaric conditions. The reaction chamber is also equipped with temperature control.

The reaction tube was placed in the high pressure reaction chamber, and the pressure was brought to $20,000 \mathrm{psi}$, at which point it was heated to $150^{\circ} \mathrm{C}$. Heating causes the pressure to rise to approximately 40,000 psi, after which the remaining pressure was applied to bring the chamber to the desired pressure $(130,000 \mathrm{psi})$, and allowed to stand under these conditions for 5 hours. The heat was then turned off and the chamber cooled overnight, during which time the pressure fell to 90,000 psi. The pressure was then released, the reaction tube removed, and the polymer precipitated by pouring into $\mathrm{MeOH}$. The polymer was then collected by centrifugation and dried. 
Table: Effect of hyperbaric conditions and crosslinking agents

$\begin{array}{ccc}\text { Pressure (atm) } & \text { Mole \% Crosslinkers } & \text { Number Average MW (PDI) } \\ 8800 & 0 \% & 6,000(2) \\ 8800 & 0 \% & 13,000(2) \\ & 5 \% & 42,000(5)\end{array}$

Preparation of Films: A solution of $0.25 \mathrm{~g}$ poly(vinyl chloride) and $2.5 \mathrm{mg}$ of polyiptycene were dissolved in $30 \mathrm{~mL} 1,2$-dichloroethane and heated to $80^{\circ} \mathrm{C}$ for 1 hour to completely dissolve the polymers. The hot solution was then poured into a $9 \mathrm{~cm}$ diameter glass petri dish, partially covered and allowed to dry slowly overnight. The film was then peeled from the dish, cut into strips, and used in polarized fluorescence experiments.

Polarized Fluorescence Experiments: These experiments were performed using a SPEX Fluorolog- $\tau 3$ equipped with polarization accessories. Excitation spectra were obtained by exciting the sample with either vertically or horizontally polarized light and collecting the total emission. The emission was monitored at $460 \mathrm{~nm}$, while the excitation wavelength was typically scanned from $330 \mathrm{~nm}$ to $400 \mathrm{~nm}$.

Before uniaxial stretching of the film was carried out, excitation spectra of the isotropic film using each of the two polarization directions were acquired. The ratio of the two intensities at each excitation wavelength created a correction factor file that factored out the inherent anisotropy of the instrument. The same film was then heated to ca. $100^{\circ} \mathrm{C}$ in an oven (above the glass transition temperature of PVC) and stretched uniaxially in a mechanical stretcher to a draw ratio of $\sim 5$.

The stretch-aligned film was placed in the fluorimeter sample chamber with the stretching direction aligned vertically, and two excitation spectra with vertically or horizontally polarized light were acquired. To ensure data reproducibility, the film was then rotated ninety degrees in the sample chamber, and the same spectra were acquired. Multiplication of the horizontally polarized excitation spectrum by the correction factor file gave the corrected excitation spectra. Excitation spectra showed excellent reproducibility and self-consistency. 


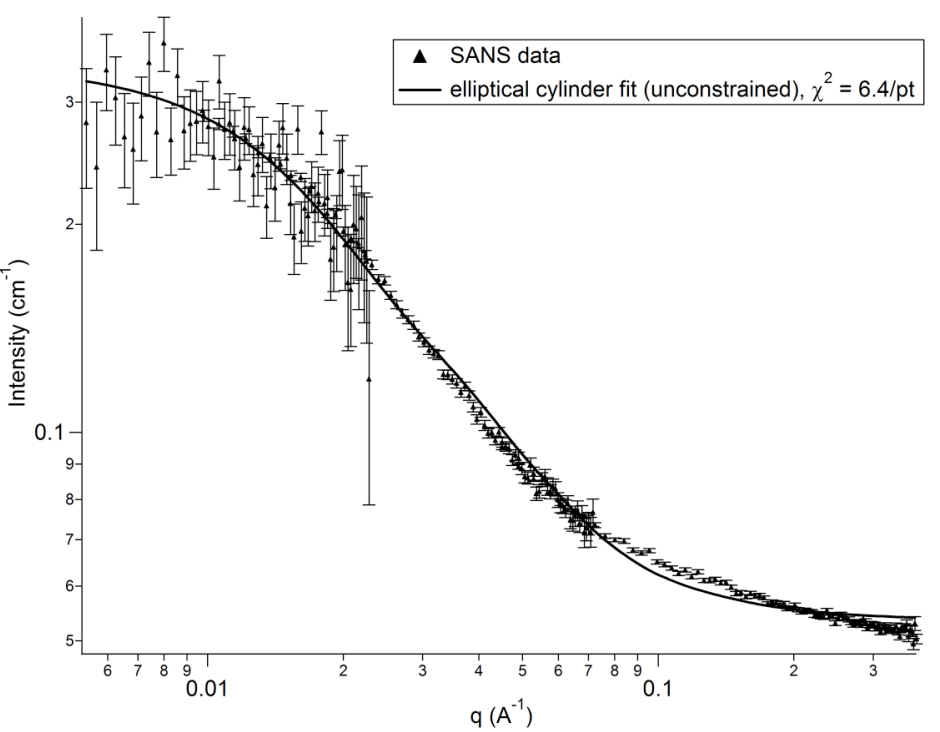

Figure S1. SANS data of $1.0 \mathrm{mg} / \mathrm{mL}$ poly-1 in $\mathrm{THF}-\mathrm{d}_{10}$, with standard deviations indicated, together with the weighted fit to an elliptical cylinder form factor.

\section{Supplemental Information References:}

(1) Perrin, D. D.; Amarego, W. L. F.; Perrin, D. R. Purification of Laboratory Chemicals; Pergamon: Oxford, 1988, $3^{\text {rd }}$ ed.

(2) Hua, D. H.; Tamura, M.; Huang, X.; Stephany, H. A.; Helfrich, B. A.; Perchellet, E. M.; Sperfslage, B. J.; Perchellet, J.-P.; Jiang, S.; Kyle, D. E.; Chiang, P. K. J. Org. Chem. 2002, 67, 2907.

(3) Long, T. M.; Swager, T. M. Adv. Mater. 2001, 13, 601.

\section{Complete Reference From Text (3a)}

Percec, V.; Dulcey, A. E.; Balagurusamy, V. S. K.; Miura, Y.; Smidrkal, J.; Peterca, M.; Nummelin, S.; Edlund, U.; Hudson, S. D.; Heiney, P. A.; Duan, H.; Magonov, S. N.; Vinogradov, S. A. Nature 2004, 430, 764. 